\title{
UKRANIAN EFFORTS TO ELIMINATE DISCRIMINATION AGAINST WOMEN
}

\section{ЗУСИЛЛЯ УКРАЇНИ ЩОДО УСУНЕННЯ ДИСКРИМІНАЦЇ̈ ЖІНОК}

\author{
Kachynska M.O., Candidate of Law, Associate Professor, \\ Associate Professor at the Department of Police Activity and Public Administration \\ Kharkiv National University of Internal Affairs
}

The article considers the issue of Ukrainian efforts to eliminate discrimination against women. The author points out that equality, equal opportunities for self-realization for everyone without exception in society is the key to building a true democratic society, in which the main goal is justice, humanity and respect for the rights and freedoms of everyone.

The article states that, unfortunately, discrimination against women is present in some form in almost every country in the world. This violation of women's rights occurs in a woman's family, public life (for example, at work, in the exercise of her civil rights, namely in voting, choosing a profession, etc.). The causes and conditions that contribute to discrimination against women's rights may vary from country to country, but they all boil down to certain traditional approaches to the role of women in society.

The author analyzes international treaties in the field of preventing and combating discrimination against women's rights. The definition of "discrimination of women's rights" is given. Attention is drawn to the provisions of the UN Convention on the Elimination of All Forms of Discrimination against Women and the Optional Protocol to this Convention.

The author analyzes in detail the powers of the Committee on the Elimination of Discrimination against Women, namely: consideration of reports of discrimination against women's rights; making recommendations on certain provisions of the Convention on the Elimination of All Forms of Discrimination against Women; and provides comments on reports of the countries party to this agreement. Attention is drawn to the existence of conditions under which the Committee may not accept reports of discrimination against women.

The author analyzed some provisions of the Concluding Observations to the Eighth Periodic Report of Ukraine on Ukraine's Implementation of the UN Convention on the Elimination of All Forms of Discrimination against Women.

Key words: discrimination against women's rights, international conventions, Committee on the Elimination of Discrimination against Women, report on discrimination against women's rights, report on the implementation of the Convention, recommendations of the Committee on the Elimination of Discrimination against Women.

У статті розглянуто питання: Україна проти дискримінації щодо жінок. Автор вказує, що рівноправність, однакова можливість самореалізації для кожної без виключень особи в суспільстві є запорукою побудови справжнього демократичного суспільства, в якому головною метою $є$ справедливість, людяність та повага до прав і свобод кожного.

У статті вказано, що, на жаль, практично в кожній державі світу присутня в тій чи іншій мірі дискримінація жінок. Означене порушення прав жінок трапляється в родині, громадському житті жінки (наприклад, на роботі, в реалізації їі громадянських прав, а саме під час голосування, в обранні професії тощо). Причини та умови, що сприяють дискримінації прав жінок, можуть відрізнятись від країни до країни, однак усі вони зводяться до певних традиційних підходів щодо ролі жінки в суспільстві.

Автор аналізує міжнародні договори у сфері запобігання та протидії дискримінації прав жінок. Наведено дефрініцію поняття «дискримінація прав жінок». Звернуто увагу на положення Конвенції ООН про ліквідацію всіх форм дискримінації щодо жінок та Факультативного протоколу до цієї конвенції.

Автор детально аналізує повноваження Комітету з ліквідації дискримінації щодо жінок, а саме: розгляд повідомлень про дискримінацію прав жінок; надання рекомендації щодо окремих положень Конвенції про ліквідацію всіх форм дискримінації стосовно жінок; надання зауважень щодо доповідей країн-учасниць цього договору. Звернуто увагу на існування умов, за яких повідомлення про дискримінацію жінок Комітет може не прийняти

Автор проаналізував окремі положення Заключних зауважень до восьмої періодичної доповіді України щодо виконання Україною Конвенції ООН про ліквідацію всіх форм дискримінації щодо жінок.

Ключові слова: дискримінація прав жінок, міжнародні конвенції, Комітет з ліквідації дискримінації щодо жінок, повідомлення про дискримінацію прав жінок, звіт про виконання положень Конвенції, рекомендацій Комітету з ліквідації дискримінації щодо жінок.

Equality, equal opportunity for self-realization for every person without exception in society is the key to building a true democratic society, in which the main goal is justice, humanity and respect for the rights and freedoms of everyone. Unfortunately, in almost every country in the world there is to some extent discrimination against women. This violation of women's rights occurs in a woman's family, public life (for example, at work, in the exercise of her civil rights, namely in voting, choosing a profession, etc.). The causes and conditions that contribute to discrimination against women's rights may vary from country to country, but they all boil down to certain traditional approaches to the role of women in society. This role of a woman, as a rule, is recessive in relation to the role of a man [1, p. 42].

At the international level, discrimination against women's rights has been the subject of debate for the past 50 years. A number of international treaties have been adopted that provide for the principles of preventing and combating discrimination against women. Ukraine is an active participant in this process and, therefore, seeks to fulfill its commitments in this area.

The essence of the concept of discrimination against women is provided in the UN Convention on the Elimination of All Forms of Discrimination against Women of Decem- ber 18,1979 . The latter states that it is any distinction, exception or restriction on the grounds of sex aimed at weakening or nullifying the recognition, use or exercise of women, regardless of their marital status, on the basis of equality between men and women, human rights and fundamental freedoms in political life, economic, social, cultural, social or any other field [2]. The Convention provides the basis for realizing equality between women and men through ensuring women's equal access to, and equal opportunities in, political and public life - including the right to vote and to stand for election - as well as education, health and employment [3].

Ukraine, as a party to the above-mentioned Convention, takes the following measures to prevent and combat discrimination against the rights of women and girls in the social and political life of the state:

- provides representatives of both sexes with the right to elect and be elected during all elections and referendums to all publicly elected bodies;

- provides equal opportunities for women and men to participate in the formation and implementation of the policy of the Cabinet of Ministers of Ukraine, to hold public office, including to perform all public functions at all levels of government; 
- provides women and men with the right to participate in the activities of non-governmental organizations dealing with issues of civil and political life of the country [2].

In order to report on the work done every 4 years to implement the provisions of the UN Convention on the Elimination of All Forms of Discrimination against Women, Ukraine will submit a report. The structure of the latter provides for the submission of the General Comments on the previous report, as well as the report on the implementation of each article documents [2].

Pursuant to the provisions of Section 5 of the Convention on the Elimination of All Forms of Discrimination against Women, a Committee on the Elimination of Discrimination against Women (CEDAW) is envisaged [4]. The Committee's mandate and the administration of the treaty are defined in Articles 17 to 30 of the Convention. The Committee is composed of 23 experts nominated by their Governments and elected by State parties as individuals "of high moral standing and competence in the field covered by the Convention" [5].

It is important to remember that on November 6, 1999, the Optional Protocol to this Conference (hereinafter the Optional Protocol) was adopted to improve the proper implementation of the provisions of the UN Convention on the Elimination of All Forms of Discrimination against Women. This Protocol clarifies the competence and activities of the Committee on the Elimination of Discrimination against Women (hereinafter referred to as the Committee). In order to improve the situation regarding the elimination of discrimination against women, to counteract any forms of violation of women's rights, the powers of the said committee include consideration of the report on discrimination against women's rights. Such notifications may be made by or on behalf of persons or groups of persons falling under the jurisdiction of a State Party who claim to be victims of a violation by a State Party of any of the rights provided for in the UN Convention on the Elimination of All Forms of Discrimination against women. However, a person (or group of persons) who has exhausted all available domestic remedies has the right to apply to the Committee, except in cases where the use of such remedies is unduly delayed or unlikely to produce a positive result [6].

The Committee has the right not to accept a notification under Article 4 of the Optional Protocol if one of the following conditions is met:

- the same issue has already been considered by the designated body or has been or is being considered in accordance with another procedure of international review or settlement;

- the issue is incompatible with the provisions of the Convention on the Elimination of All Forms of Discrimination against Women;

- the issue is insufficiently substantiated or is clearly unfounded;

- the issue is an abuse of the right to send such a notice;

- the facts which are the subject of the communication took place before the entry into force of this Protocol for the State Party concerned, unless those facts took place after that date [6].

The importance of the Committee's recommendations on the elimination of discrimination against women should also be borne in mind. These recommendations are made on any issues concerning women, and to which the parties to the treaty should pay more attention. For example, at its 1989 session, the Committee discussed the high frequency of violence against women and, as a result, demanded reports from all members. In 1992, the Committee adopted general recommendation № 19 , which requires the following to be included in the reports of participating countries:

- statistics on the level of violence against women;

- information on the provision of services to victims;

- on legislative and other measures taken to protect women from violence in everyday life, in particular, on sexual harassment at work, domestic violence, sexual violence [7].
It should be noted that the Committee on the Elimination of Discrimination against Women also makes recommendations on certain provisions of the Convention on the Elimination of All Forms of Discrimination against Women. For example, there is only one article in the Convention that draws the attention of States to the multiple discrimination against rural women.

In the General Recommendations, the said Committee expands the list of factors that may exacerbate discrimination. These factors included circumstances affecting women's lives, namely: ethnicity / race, indigenous or minority status, skin colour, socio-economic status and/or caste, language, religion or belief, political opinion, national origin, marital and/or maternal status, age, urban/rural residence, health status, disability, property, sexual orientation, gender identity and intersex characteristics, illiteracy, trafficking in women, armed conflict, asylum, refugee status, internal displacement, statelessness, migration, households, widowhood, living with HIV / AIDS, imprisonment, prostitution, geographical remoteness and stigmatization of women fighting for their rights, including human rights defenders [8].

The Committee on the Elimination of Discrimination against Women also comments on the reports of participating countries. For example, in its Concluding Observations to the Eighth Periodic Report of Ukraine on Ukraine's Implementation of the UN Convention on the Elimination of All Forms of Discrimination against Women (hereinafter: the Committee on the Elimination of Discrimination against Women), it expressed concern about the following.

In Ukraine, patriarchal views and discriminatory stereotypes about the role and responsibilities of women and men in the family are still deeply ingrained in political discourse, the media and society. These views perpetuate the subordinate position of women in the family and society. This is reflected in the choice of women in education and professional activities, expressed by their limited participation in political and social life, their unequal participation in the labour market and unequal position in family relations. It is noted that these discriminatory stereotypes are also key causes of violence against women. Concerns were expressed that to date, Ukraine has not taken permanent measures to change or eliminate discriminatory stereotypes and negative traditional approaches [9].

Analyzing the issue of education in Ukraine, the Committee on the Elimination of Discrimination against Women noted the high level of literacy among women, as well as the development of the Education Strategy 2020. However, there are negative and patriarchal stereotypes about women and girls in the school curriculum. In addition, special attention was paid to conducting "labour lessons" in schools. During such lessons, girls are taught to cook and sew, while boys are taught carpentry and joinery skills. It upholds traditional gender roles in society. Unequal access for women to higher education institutions of the Ministry of Internal Affairs and the Ministry of Defense was stated. The Committee is also concerned about the high drop-out rates among girls belonging to the Roma community. In the light of these comments, the Committee on the Elimination of Discrimination against Women recommends that Ukraine:

- intensify efforts to review school curricula and textbooks to eliminate negative stereotypes about women and girls;

- ensure the use of the same curriculum for boys and girls, in particular, it is proposed to introduce the same "work lessons" for boys and girls, including through the adoption of temporary special measures;

- provide women with equal access to the universities of the Ministry of Internal Affairs and the Ministry of Defense, including through the adoption of temporary special measures;

- Encourage Roma girls' access to education and ensure their continuing education at all levels of education by raising awareness of the importance of education as a human right and as a basis for women's empowerment, and strengthening 
the implementation of re-entry policies that allow Roma girls who left school to return to school [11].

In pursuance of the above recommendations and a number of other provisions set out in the Remarks, the Cabinet of Ministers of Ukraine by Order № 634-r of September 5, 2018 approved the National Action Plan to implement the recommendations set out in the concluding observations of the UN Committee on the Elimination of Discrimination against Women. Ukraine on the implementation of the Convention on the Elimination of All Forms of Discrimination against Women for the period up to 2021 [11].
Thus, the concept of equality between women and men can be achieved through an objective study of the causes and conditions that contribute to it, and the taking of all measures that promote it. It is this concept that has formed the basis of the Convention on the Elimination of All Forms of Discrimination against Women. The comments of the UN Committee on the Elimination of Discrimination against Women help Ukraine, as well as other countries, to pay more attention to improving the implementation of the commitments made in the field of preventing and combating discrimination against women.

\section{REFERENCES}

1. Kachynska M. Gender Equality in Ukraine: National and International Perspectives. 2018. № 3. P. 40-47.

2. Конвенція Організації Об'єднаних Націй про ліквідацію всіх форм дискримінації щодо жінок (укр/рос) : Міжнародний документ від 18.12.1979 p. URL: https://zakon.rada.gov.ua/laws/show/995_207

3. Convention on the Elimination of All Form of Discrimination against Woman. Official Web-page UN WOMEN. URL: https://www.un.org/ womenwatch/daw/cedaw/cedaw.htm

4. Конвенция о ликвидации всех форм дискриминации в отношении женщин. Офріційний Веб-сайт UN WOMEN. URL: https://www.un.org/womenwatch/daw/cedaw/text/0360795R.pdf

5. Convention on the Elimination of All Forms of Discrimination against Women. New York, 18 December 1979. Official Web-page United Nations Human Rights Officer of the Hight Commissioner. URL: https://www.ohchr.org/EN/Professionallnterest/Pages/CEDAW.aspx

6. Факультативний протокол до Конвенції про ліквідацію усіх форм дискримінації стосовно жінок : міжнародний договір від 06 жовтня 1999 року. URL: https://zakon.rada.gov.ua/laws/show/995_794

7. General recommendations: official web-page of United Nations Human Rights Offiser of the High Commissioner. URL: https://www.ohchr.org/EN/HRBodies/CEDAW/Pages/Recommendations.aspx

8. Загальні рекомендації ухвалені Комітетом ОOH з ліквідації дискримінації щодо жінок № 1-37. URL: https://land.gov.ua/wp-content/ uploads/2019/01/\%D0\%97\%D0\%B0\%D0\%B3\%D0\%B0\%D0\%BB\%D1\%8C\%D0\%BD\%D1\%96-\%D1\%80\%D0\%B5\%D0\%BA\%D0\%BE\%D0 \%BC\%D0\%B5\%D0\%BD\%D0\%B4\%D0\%B0\%D1\%86\%D1\%96\%D1\%97-\%D0\%9A\%D0\%BE\%D0\%BC\%D1\%96\%D1\%82\%D0\%B5\%D1\%82 \%D1\%83-\%D0\%9E\%D0\%9E\%D0\%9D.pdf

9. Заключні зауваження до восьмої періодичної доповіді України. Комітет з ліквідації дискримінації щодо жінок. 03.03.2017р. URL: http://mip.gov.ua/files/documents/Zakluchni_zauvazhennya_Komitetu_OON.pdf

10. Заключні зауваження до восьмої періодичної доповіді України. Комітет з ліквідації дискримінації щодо жінок. 03.03.2017р. URL: http://mip.gov.ua/files/documents/Zakluchni_zauvazhennya_Komitetu_OON.pdf

11. Про затвердження Національного плану дій 3 виконання рекомендацій, викладених у заключних зауваженнях Комітету $\mathrm{OOH}$ з ліквідації дискримінації щодо жінок до восьмої періодичної доповіді України про виконання Конвенції про ліквідацію всіх форм дискримінації щодо жінок на період до 2021 року : Розпорядження Кабінету Міністрів України № 634-p від 05.09.2018 p. URL: https://zakon.rada.gov.ua/laws/show/634-2018-\%D1\%80 